$\begin{array}{ll}\text { Dikumpulkan } & : 17 \text { Mei } 2019 \\ \text { Diterima } & : 15 \text { Agustus } 2019 \\ \text { DOI } & : \text { https://doi.org/10.22146/jpt.48836 }\end{array}$

\title{
Strategi Pengembangan Destinasi Wisata Berbasis Folklor (Ziarah Mitos: Lahan Baru Pariwisata Indonesia)
}

\author{
Tri Amanat \\ Badan Pengembangan Bahasa dan Perbukuan, Kementerian Pendidikan dan \\ Kebudayaan \\ 3amanat@gmail.com
}

\begin{abstract}
The tourism sector is a national priority in the 2015-2019 RPJM of the Jokowi-JK government. Various parties can play an active role in opening new tourist destinations, both at local, regional, and even international levels. Many myths and legends in the community that can be used as a basis for determining the development of new tourist sites. This study used descriptive qualitative method. Recommendation material for regional selection / selection to be developed as folklore-based tourist destinations can be applied in the form of categories. The category in question is adapted from Irina-Maria Necheş (2013) as follows; the presence or absence of tangible and intangible values to be appointed, the classification of the principal values to be raised, whether mythological, religious, or historical. In other words, the effort to form an image as a regional tourism selling power in question is developed based on cultural ideas (which can be abstract) and then concretized so that visitors can enjoy them sensually.
\end{abstract}

Keywords: folklores, tourism location development, mythological value, religious value, historical value 


\section{PENDAHULUAN}

Sektor pariwisata menjadi prioritas nasional dalam RPJM 20152019 pemerintahan Jokowi-JK. Pariwisata merupakan salah satu dari 5 (lima) sektor prioritas pembangunan 2017 yang meliputi; pangan, energi, maritim, pariwisata, kawasan industri dan Kawasan Ekonomi Khusus (KEK). Di akhir pemerintahan Jokowi-JK pada tahun 2019 ditargetkan turis asing berkunjung berjumlah 20 juta orang, sedangkan turis dalam negeri berjumlah 275 juta orang. Bahkan pada periode 2010-2014 pariwisata telah menjadi sektor ke empat terbesar sebagai penyumbang PDB nasional setelah migas, batu bara, dan kelapa sawit. Pariwisata telah menyumbang devisa sebesar 10 milyar USD, menyerap 10,13 juta tenaga kerja, menarik kunjungan turis asing sebanyak 9,4 juta orang, dan transaksi 250 juta perjalanan wisata dalam negeri dengan perbelanjaan sebesar 177 triliun rupiah pada tahun 2014 (Kemenpar, 2015, hlm. 5).

Pencapaian tersebut tak lepas pula dari keberhasilan country branding "Wonderful Indonesia" yang awalnya tidak masuk ranking branding di dunia, pada tahun 2015 melesat lebih dari 100 peringkat menjadi ranking 47 , menyalip country branding "Truly Asia Malaysia" (ranking 96) dan country branding "Amazing Thailand" (ranking 83). Hal ini menunjukkan country branding "Wonderful Indonesia" mencerminkan Positioning dan Differentiating Pariwisata Indonesia di level dunia.

Kini Indonesia sedang mengembangkan 10 Destinasi Prioritas yang di harapkan menarik turis asing berkunjung yaitu; Danau Toba di Sumatera Utara, Borobudur di Jawa Tengah, Mandalika di Nusa Tenggara Barat, Bromo-Tengger-Semeru di Jawa Timur, Labuan Bajo di Nusa Tenggara
Timur, Tanjung Kelayang di Bangka dan Belitung, Kepulauan Seribu di DKI Jakarta, Tanjung Lesung di Banten, Moratai di Maluku Utara. Namun jumlah tersebut dirasa belum berimbang dengan ribuan potensi kekayaan yang dimiliki berbagai daerah di Indonesia. Hal itu bisa dimaklumi mengingat keterbatasan anggaran maupun sumber daya lainnya yang dimiliki oleh pemangku kepentingan.

Pada posisi inilah pihak pemda baik provinsi ataupun kabupaten/kota maupun sektor swasta dan masyarakat dapat berperan aktif dalam membuka destinasi wisata baru, baik berlevel lokal, regional, bahkan internasional. Pintu kedatangan pun perlu lebih diperbanyak lagi mengingat saat ini kebanyakan para turis asing tersebut hanya masuk melalui lima pintu yaitu; Kuala Namu, Medan (Sumut), Batam (Kepri), Tanjung Uban (Kepri), Bandara Soekarno-Hatta (Banten), dan Bandara Ngurah Rai (Bali) (Katadata, 2014). Akses-akses opsional pun perlu lebih diperluas karena terkait langsung dengan komponen penunjang industri wisata lainnya.

Salah satu keunikan Indonesia yang mengagumkan dan diakui dunia adalah keberagaman budaya dari ratusan suku yang ada. Menurut sensus BPS tahun 2010 setidaknya terdapat 1.340 suku bangsa bermukim di berbagai pelosok Nusantara. Masing-masing suku dengan latar ragam agama, adat budaya, dan kondisi sosial tersebut tentu saja menyimpan banyak hal yang dapat menarik kedatangan turis. Namun Tentu perlu adanya riset dan kajian dari ribuan lokasi dengan potensinya masingmasing. Dalam hal ini skala prioritas perlu menjadi bahan pertimbangan. Salah satu langkah dalam penentuan lokasi tujuan wisata baru adalah dengan melakukan kajian berdasar warisan budaya berupa folklor khususnya yang 
berdasar mitos dan legenda daerah setempat.

Banyak mitos dan legenda di masyarakat yang dapat dijadikan landas penentu pengembangan lokasi wisata baru. Tentu saja mitos dan legenda yang ada tersebut perlu dikemas atau "dimanipulasi" dalam rangka menarik pengunjung. Salah satu contoh obyek wisata yang berhasil berkembang dengan memberdayakan warisan folklor yang ada adalah pantai Air Manis di Sumatra Barat. Folklor yang mampu mendongkrak nama pantai Air Manis adalah cerita rakyat Si Malin Kundang. Paduan popularitas kisah Malin Kundang dengan manipulasi visual berupa bentuk karang (yang dipahat) yang menggambarkan peristiwa dikutuknya Malin Kundang menjadi batu terbukti mampu memantik rasa penasaran turis sehingga berkeinginan untuk mengunjunginya.

Sejauh pengetahuan penulis kajian pengembangan tujuan wisata baru berdasar budaya memang telah banyak dilakukan namun yang menghususkan kajian pengembangan dengan berbasis folklor khususnya kisahkisah lokal baik mitos maupun legenda belum banyak dieksplorasi. Beberapa kajian terkait pengembangan tujuan wisata berbasis budaya misalnya seperti yang dilakukan oleh Hamim Farhan dan R. Nazriyah (2009) yang berjudul "Pengembangan Pariwisata Berbasis Budaya Lokal-Budaya Religi sebagai Upaya Pendukung Peningkatan Industri Pariwisata Daerah Gresik". Kajian ini menunjukkan bahwa karakteristik daerah Gresik sedari dulu merupakan daerah yang erat dan identik dengan unsur-unsur budaya Islam karena memang merupakan salah satu titik tolak penyebaran Islam di Jawa. Kajian ini merekomendasikan model konsep pengembangan pariwisata di Kota Gresik seperti penentuan karakter perjalanan, desain, desain tata letak wisata kota, pertunjukan dan area strategi yang ditampilkan dengan wisata potensial dengan mengusung tema khas lokal tersebut yaitu, berbasis budaya Islam.

Kajian lainnya adalah yang dilakukan Masri Ridwan dkk (2016) yang berjudul “ Potensi Objek Wisata Toraja Utara Berbasis Kearifan Lokal sebagai Sumber Materi Geografi Pariwisata" Hasil penelitian adalah (1) kawasan obyek wisatan Toraja Utara memiliki potensi wisata budaya, alam dan sejarah (2) Pengelola kawasan wisata Toraja Utara diantaranya: Yayasan, Petani, Pemda, dan Keluarga.

Pengembangan Objek wisata berbasis kearifan lokal setempat mendukung kelangsungan wisata di Toraja Utara. (4) Wisata Toraja Utara berbasis kearifan lokal dapat digunakan sebagai sumber materi belajar M.k Geografi Pariwisata Jurusan Geografi FMIPA Universitas Negeri Makassar yakni Materi Potensi Wisata lokal.

Kajian selanjutnya adalah yang dilakukan oleh Nurdin (2016) berjudul "Strategi Pengembangan Pariwisata Berbasis Masyarakat di Pulau Samalona, Makassar". Hasil kajian melalui analisis SWOT, Pulau Samalona sangat layak untuk dikembangkan sebagai tujuan wisata berbasis masyarakat dengan alam dan potensi sosio-kultural. Strategi yang diterapkan dalam menjawab hasil SWOT adalah sebagai berikut; strategi kekuatan-kesempatan (S-O) dengan strategi pembangunan pariwisata tujuan dan strategi pengembangan daya tarik wisata, strategi ancaman kekuatan (S-T) dengan strategi perbaikan kualitas lingkungan, strategi pembangunan yang berkelanjutan pariwisata, strategi kelemahan-peluang (W-O) dengan strategi promosi tujuan wisata, sedangkan strategi ancaman kelemahan 
(W-T) dengan strategi pembangunan sumber daya manusia dan strategi pengembangan kelembagaan dan pengelolaan tujuan.

Kajian yang akan dilaksanakan ini berusaha mengisi kerumpangan terkait pengembangan tujuan wisata baru dengan menawarkan sebuah konsep alur penilaian dalam menentukan prioritas pemilihan suatu lokasi untuk dikembangkan sebagai tujuan wisata baru dengan berpijak pada kriteriakriteria tertentu. Kriteria-kriteria yang dimaksud dikembangkan dari folklor berupa cerita-cerita lokal terutama mitos dan legenda yang ada sebagai basis data dan karakteristik budaya lokal sebagai pendukungnya. hal itu perlu ditempuh sehingga warisan-warisan budaya yang dimiliki dapat bermanfaat dan dimanfaatkan oleh pemiliknya. Dengan demikian setidaknya didapatkan dua manfaat sekaligus yaitu, masyarakat pemilik warisan budaya berupa folklor meningkat taraf ekonominya sekaligus kekayaan budaya mereka terjaga. Sistematika penilaian yang disusun dalam kajian ini diharapkan memberi alternatif bagi pihak-pihak terkait dan pemangku kebijakan dalam menentukan pengembangan lokasi potensi pariwisata baru.

\section{TINJAUAN PUSTAKA}

Agar diperoleh gambaran yang utuh dan kesamaan persepsi ada baiknya kajian pustaka dimulai dengan memahami istilah-istilah yang terkait dalam makalah ini terutama mengenai kepariwisataan dan folklor. Untuk mendapatkan gambaran yang lebih jelas tentang kepariwisataan berikut definisi dalam menjabarkan kata-kata yang berhubungan dengan kepariwisataan: 1). Wisata: Perjalanan, dalam bahasa Inggris disebut dengan "Travel". 2). Pariwisata: Perjalanan yang dilakukan dari satu tempat ke tempat lain, dalam bahasa Inggris disebut dengan "Tour". 3). Wisatawan: Orang yang melakukan perjalanan, dalam bahasa Inggris disebut dengan "Travelers". 4). Kepariwisatan: Hal-hal yang berhubungan dengan pariwisata dan dalam bahasa Inggris disebut dengan "Tourisme" (Irawan, 2010:11).

Perkembangan teknologi terutama teknologi informasi khususnya menjamurnya media sosial ikut menyuburkan pula titik-titik destinasi wisata. Keberadaan Path, Instagram, Facebook dan sejenisnya memunculkan pula jenis-jenis lokasi pariwisata baru yang dalam istilah anak muda masa kini adalah lokasi yang instagramable. Sementara itu Host and Guest (1989) dalam Kusumaningrum (2009: 3) mengklasifikasikan jenis pariwisata sebagai berikut: 1). Pariwisata Etnik (Etnhic Tourism) yaitu, perjalanan untuk mengamati perwujudan kebudayaan dan gaya hidup masyarakat yang menarik. 2). Pariwisata Budaya (Culture Tourism) yaitu, perjalanan untuk meresapi atau untuk mengalami gaya hidup yang telah hilang dari ingatan manusia. 3). Pariwisata Rekreasi (Recreation Tourism) yaitu, kegiatan pariwisata yang berkisar pada olahraga, menghilangkan ketegangan, dan melakukan kontak sosial dengan suasana santai. 4). Pariwisata Alam (Eco Tourism) yaitu, perjalanan kesuatu tempat yang relatif masih asli atau belum tercemar, dengan tujuan untuk mempelajari, mengagumi, menikmati pemandangan, tumbuhan, dan binatang liar, serta perwujudan budaya yang ada atau pernah ada di tempat tersebut. 5). Pariwisata Kota(City Tourism), yaitu, perjalanan dalam suatu kota untuk menikmati pemandangan, tumbuhan, dan binatang liar, serta perwujudan budaya yang ada atau pernah ada di 
tempat tersebut. 6). Rersort City yaitu, kota atau perkampungan yang mempunyai tumpuan kehidupan pada persediaan sarana atau prasarana wisata meliputi; penginapan, restoran, olahraga, hiburan dan persediaan tamasya lainnya. 7). Pariwisata Agro (Agro Tourism yang terdiri dari Rural Tourism atau Farm Tourism) yaitu, merupakan perjalanan untuk meresapi dan mempelajari kegiatan pertanian, perkebunan, peternakan, kehutanan. Jenis wisata ini bertujuan mengajak wisatawan memikirikan alam dan kelestariannya.

Keberhasilan beragam jenis pariwisata tersebut dalam menarik pengunjung juga dipengaruhi oleh faktor-faktor atau unsur pendukungnya. Unsur-unsur tersebut meliputi hal-hal sebagai berikut (Pendit, 1994); 1). Akomodasi, tempat seseorang untuk tinggal sementara. 2). Jasa Boga dan Restoran, industri jasa di bidang penyelenggaraan makanan dan minuman yang dikelola secara komersial. 3). Transportasi dan Jasa Angkutan, industri usaha jasa yang bergerak di bidang angkutan darat, laut dan udara. 4). Atraksi Wisata, kegiatan wisata yang dapat menarik perhatian wisatawan atau pengunjung. 5). Cinderamata (Souvenir), benda yang dijadikan kenang-kenangan untuk dibawa oleh wistawan pada saat kembali ke tempat asal. 6). Biro Perjalanan, badan usaha pelayanan semua proses perjalanan dari berangkat hingga kembali.

Setelah membahas hal terkait kepariwisataan ada baiknya pula dibahasa istilah seputar folklor. Kata folklor adalah pengindonesian dari kosa kata Inggris folklore. Kata itu adalah kata majemuk, yang berasal dari dua kata dasar folk dan lore. Menurut Alan Dundes (dalam Danandjaja, 2007: 1), folk adalah sekelompok orang yang memilki ciri-ciri pengenal fisik, sosial, dan kebudayaan, sehingga dapat dibedakan dari kelompok-kelompok lainnya. Jadi folk adalah sinonim dengan kolektif, yang juga memiliki ciri-ciri pengenal fisik atau kebudayaan yang sama, serta mempunyai kesadaran kepribadian sebagai kesatuan masyarakat. Sedangkan yang dimaksudkan dengan lore adalah tradisi folk, yaitu sebagian kebudayaannya, yang diwariskan secara turun-temurun secara lisan atau melalui suatu contoh yang disertai dengan gerak isyarat atau alat pembantu pengingat (mnemonic device).

Selanjutnya secara singkat Djamaris (1993: 16) mengatakan bahwa folklor merupakan salah satu cabang ilmu Antropologi. Jadi, dari beberapa pengertian dari folklor tersebut dapat ditarik kesimpulan bahwa folklor adalah cabang ilmu Antropologi yang mempelajari tentang kebudayaan di suatu masyarakat yang telah diwariskan secara turun temurun. Dari penelitian folkor kita dapat mengetahui kebudayaan suatu bangsa sebelum 'tersentuh' pengaruh kebudayaan asing. Kebudayaan suatu bangsa tersebut antara lain kepercayaan, pandangan hidup, adat istiadat, dan cara berpikir masyarakat bangsa tersebut. Kemurnian budaya bangsa itulah yang menyebabkan ahli folklor tertarik meneliti sebuah cerita rakyat.

Menurut Brunvand (dalam Danandjaja: 2007: 21), seorang ahli folklor dari AS. Folklor dapat digolongkan ke dalam tiga kelompok besar berdasarkan tipenya yaitu, folklor lisan (verbal folklore), folklor sebagian lisan (partly verbal folklore), dan folklor bukan lisan (nonverbal folklore). Folklor lisan adalah folklor yang bentuknya memang murni lisan. Bentuk-bentuk (genre) folklor yang termasuk ke dalam kelompok folklor lisan ini antara lain 
adalah bahasa rakyat (folk speech) seperti; logat, julukan, pangkat tradisional, dan titel kebangsawanan. Penggolongan folklor lisan yang kedua yaitu, ungkapan tradisional seperti; peribahasa, pepatah, dan pemeo. Penggolongan folklor lisan yang ketiga yaitu; pertanyaan tradisional, contohnya teka-teki. Penggolongan folklor lisan yang keempat yaitu; puisi rakyat, seperti pantun, gurindam, dan syair. Penggolongan folklor lisan yang kelima yaitu; cerita prosa rakyat, seperti mite, legenda, dan dongeng. Penggolongan folklor lisan yang keenam yaitu, nyanyian rakyat. Potensi folklor yang paling tepat untuk dimanfaatkan adalah folklor lisan yang ke lima. Namun demikian bukan berarti jenis lainnya tidak sesuai. Bahkan jika mungkin dapat dijadikan sebagai pendukung jenis ke lima tersebut.

\section{METODE}

Berdasarkan masalah yang telah dirumuskan dalam penelitian ini, maka peneliti menggunakan metode deskriptif kualitatif. Dikatakan deskriptif karena dalam penelitian ini mendeskripsikan data berdasarkan kenyataan-kenyataan secara objektif sesuai data yang ditemukan, dan dikatakan kualitatif karena dalam menjelaskan konsepkonsep yang berkaitan satu sama lain dengan menggunakan kata-kata atau kalimat bukan menggunakan data atau statistik.

\section{PEMBAHASAN}

\section{A. Bentang Alam dan Bentang Budaya Indonesia}

Masing-masing wilayah dengan karakteristik alam tertentu akan mempunyai karakteristik budaya yang mengikutinya. Bentang alam yang ada di wilayah Indonesia terkait dan berpengaruh kepada bentang budayanya. Wilayah yang kehidupan masyarakatnya erat dengan sungai akan kaya pula dengan folklor yang berhubungan dengan sungai, demikian juga jika bentang alamnya berupa gunung, laut dan sebagainya. Dengan berdasar folklor yang dimiliki oleh suatu daerah dapat dijadikan pijakan dalam pengembangan potensinya sebagai destinasi wisata. Hal itu tentu dengan didukung pengembangan sarana dan prasarana yang dibutuhkan oleh pengunjung seperti; kemudahan transportasi, akomodasi dan sebagainya. Sebagaimana dengan contoh sebelumnya mengenai cerita Malin Kundang dari Sumatera Barat di awal makalah ini. Cerita tersebut sarat akan gambaran keterkaitan erat antara bentang alam dengan bentang budayanya, baik budaya secara fisik seperti; pantai, kapal, pelaut maupun secara mental seperti pentingnya peran ibu, berbakti kepada ibu, budaya merantau dan sebagainya.

Penggalian terhadap khazanah budaya lokal terutama folklor berjenis cerita rakyat perlu dilakukan terlebih dahulu sebagai titik pangkal. Selain itu perlu pula disusun sebuah pengkategorian dengan berlandaskan pada karakteristik dan realita budaya yang ada di Indonesia. Hal tersebut akan sangat bermanfaat dalam pemeringkatan daerah-daerah yang berpotensi untuk dikembangkan jika pemilihan dengan dasar skala prioritas. Karakteristik dan realitas yang ada dapat disusun dengan beragam cara dan metode tergantung kebutuhan. Beberapa realita dan karakteristik yang dimaksud misalnya meliputi; keragaman religi, lanskap khas yang dimiliki, nilai sosial, dan sebagainya.

Nurbaningsih dalam Jaelani (2017) menyatakan bahwa desentralisasi bidang pariwisata adalah urusan pemerintahan konkuren yang menjadi 
kewenangan dalam urusan pemerintahan pilihan. Salah satu urusan pemerintahan pilihan tersebut meliputi penyerahan urusan pemerintah pusat ke daerah untuk menetukan sumbersumber daya tarik wisata, kawasan strategis pariwisata, dan destinasi pariwisata. Secara konseptual desentralisasi pariwisata kewenangan antara pusat dan daerah ini mencakup empat hal pokok. Pertama, wewenang dan tugas daerah (expenditure assignment) dalam mengelola destinasi pariwisata. Kedua, wewenang daerah untuk memasarkan pariwisata. Ketiga, wewenang daerah untuk mengembangkan ekonomi kreatif melalui pemanfaatan dan perlindungan hak kekayaan intelektual. Keempat, wewenang daerah untuk mengembangkan sumber daya pariwisata dan ekonomi kreatif.

Dalam bidang destinasi pariwisata, Pemerintah Pusat mempunyai wewenang sebagai berikut; pertama, penetapan daya tarik wisata, kawasan strategis pariwisata, dan destinasi pariwisata. Kedua, pengelolaan daya tarik wisata nasional. Ketiga, pengelolaan kawasan strategis pariwisata nasional, keempat, pengelolaan destinasi pariwisata nasional dan penetapan tanda daftar usaha pariwisata lintas Daerah Provinsi. Adapun Pemerintah Daerah Provinsi dalam bidang destinasi pariwisata mempunyai wewenang pengelolaan daya tarik wisata provinsi, pengelolaan kawasan strategis pariwisata provinsi, pengelolaan destinasi pariwisata provinsi dan penetapan tanda daftar usaha pariwisata lintas Daerah kabupaten/kota dalam 1(satu) daerah provinsi. Sedangkan Pemerintah Daerah Kabupaten/Kota dalam bidang destinasi pariwisata mempunyai wewenang mengelola daya tarik wisata kabupaten/kota, mengelola kawasan strategis pariwisata kabupaten/kota, mengelola destinasi pariwisata kabupaten/ kota dan menetapkan tanda daftar usaha pariwisata kabupaten/kota. (Zamboni dalam Jaelani, 2017).

\section{B. Model Pengembangan Destinasi Wisata Baru Berdasar Folklor}

Pada makalah ini dipilih beberapa kategori yang dapat dimanfaatkan sebagai bahan penyusunan rekomendasi bagi penentuan/pemilihan daerah yang akan dikembangkan sebagai destinasi wisata baru berbasis kekayaan folklornya. Kategori yang dimaksud diadaptasi dari artikel Irina-Maria Necheş (2013) sebagai berikut; ada tidaknya nilai (value) naik berwujud (tangible) maupun tidak berwujud (intangible) yang hendak diangkat, pengklasifikasian nilai pokok yang hendak diangkat, apakah bernilai mitologis, religius, atau historis. Dengan kata lain upaya pembentukan citra sebagai daya jual pariwisata daerah yang dimaksud dikembangkan dengan berpijak pada ide-ide budaya (yang bisa saja abstrak) kemudian dikonkretkan agar dapat dinikmati secara inderawi oleh pengunjung. Hal itu perlu juga didukung dengan keselarasan lanskap sekitarnya. Sebagaimana yang terjadi pada obyek wisata pantai Air Manis di Sumatra Barat, ide-ide budaya dalam kisah Malin Kundang dikonkretkan secara visual dengan sebuah pahatan salah satu sekuen kisah tersebut.

Kesinambungan antar komponen pariwisata sangat penting dalam meraih keberterimaan (calon) pengunjung. Idealnya hal hal yang tangible ataupun intangible yang ada dapat dipadukan sehingga mendukung dan memperkuat narasi dari cerita rakyat yang dijadikan basis wisata daerah tersebut. Sehingga diperoleh suatu destinasi wisata yang kuat dalam hal pengaruh dan daya 
tariknya dalam durasi yang panjang. Model pengembangan destinasi wisata baru berdasar kekayaan folklor ditunjukkan dalam alur berikut;

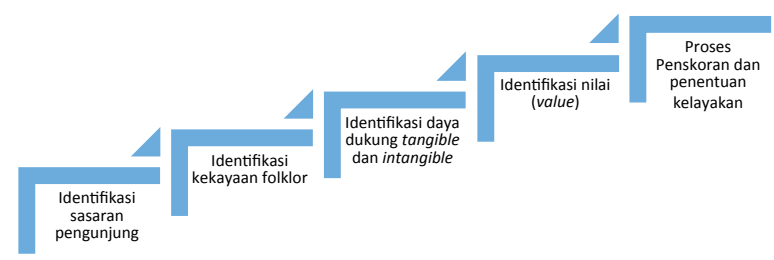

Gambar 1. Proses identifikasi dan langkah pengembangan destinasi wisata baru

Pada tahap awal setidaknya sudah diadakan kajian dan identifikasi mengenai pengunjung yang disasar, apakah destinasi wisata baru tersebut akan ditujukan untuk skala lokal, nasional, atau internasional. Selain itu apakah pengunjung yang disasar berlatar belakang khusus misalnya, berdasar kepercayaan atau religi tertentu dan sebagainya. Dengan adanya identifikasi terhadap pengunjung yang disasar ini akan dapat diperkirakan terkait berbagai hal seperti; jumlah pengunjung, kebutuhan infrastruktur yang menunjang keberadaan para pengunjung seperti penginapan, fasilitas umum dan sebagainya. Setelah identifikasi pengunjung terpetakan maka tahap selanjutnya adalah mengidentifikasi kekayaan folklor yang akan dijadikan tema dan trademark daerah yang akan dikembangkan sebagai destinasi wisata baru. Jenis folklor paling ideal untuk kebutuhan ini adalah cerita rakyat yang berbentuk narasi seperti legenda atau mite. Sehingga hal itu dapat dimanfaatkan dalam penyusunan skenario wisata yang akan dialami oleh pengunjung, sehingga pengunjung mengalami semacam ziarah mitos.

Setelah kekayaan folklor berupa cerita rakyat teridentifikasi maka pada tahap selanjutnya identifikasi daya dukung baik yang bewujud (tangible) dan tak berwujud (intangible) bisa dilaksanakan. Daya dukung yang berwujud dapat memanfaatkan apa yang telah ada (alami, apa adanya) dapat pula memodifikasi sesuai dengan apa yang dibutuhkan, demikian juga dengan yang tak berwujud. Hal tersebut perlu dilakukan agar atmosfer lokasi wisata dapat mendukung sepenuhnya dalam mencipta kesan yang kuat kepada pengunjung. Sehingga pada ujungnya para pengunjung benar-benar dapat menghayati keberadaannya berada 'di dalam' narasi cerita rakyat yang ingin dinikmatinya. Sebagaimana ketika berada di Pantai Air Manis misalnya, ditepian pantainya para pengunjung dapat menyatukan bingkai-bingkai visualnya yaitu, pantai, pahatan batu Malin Kundang yang dikutuk dan sebagainya membentuk sebuah narasi dan merangkai imajinasi mengenai kisah cerita rakyat Malin Kundang yang mungkin sebelumnya cerita tersebut hanya mereka temui dari mulut ke mulut maupun dari bacaan saja.

Tahap selanjutnya adalah identifikasi nilai (value) dari situs-situs yang ada di lokasi. Nilai yang dapat dijadikan pedoman dalam penskoran lokasi yang hendak dikembangkan sebagai destinasi wisata baru misalnya; nilai mitologis, nilai relijius, atau nilai kesejarahan. Untuk itu dapat digunakan tabel penilaian yang mampu memberikan gambaran akan potensi yang dimiliki suatu wilayah sebagaimana dicontohkan berikut ini; Nilai mitologi: Pengertian nilai mitologis dalam hal ini adalah terkait ada atau tidaknya mitos yang beredar dan terkait daerah yang hendak dikembangkan sebagai daerah tujuan wisata baru, Nilai tersebut dapat berasal dari cerita rakyat yang ada. Tinggi rendah nilai ditentukan oleh popularitas cerita rakyat tersebut, sejauh 
mana cerita tersebut masih dikenal oleh masyarakat. Selain itu sejauh mana tingkat keterpercayaan masyarakat terhadap cerita yang beredar juga dapat dijadikan salah satu variabel dalam penilaian. Unsur nilai mitologis ini dapat bersumber dari dua hal yaitu, legenda dan mitos.

Nilai religius: Nilai religius dapat dibatasi pada sekadar keterkaitas situs dengan agama tertentu ataupun ditarik ke wilayah lebih luas lagi. Contoh yang sudah ada misalnya, adalah Sendang Sriningsih di Kabupaten Klaten yang erat kaitannya dengan ziarah Bunda Maria atau Rawa Jimbung yang diyakini tempat bersemayam Bulus Jimbung, bulus (kurakura) sakti yang dapat membantu mengabulkan keinginan para pengunjung. Nilai relijius ini dapat bersumber dari nilai sejarah maupun prasejarah.

Nilai yang terakhir adalah nilai kesejarahan: pengertian nilai kesejarahan ini terkait dengan buktibukti yang nantinya dapat atau tidak dapat dibuktikan secara fisik karena hal inilah salah satu faktor penguat dalam menarik perhatian (calon) pengunjung. Nilai arkeologis terkait erat dengan bukti-bukti bendawi atau artefak yang dapat disaksikan oleh para pengunjung. Sedangkan nilai dokumentasi dapat berupa catatan-catatan seperti manuskrip maupun diorama-diorama.

Pada dasarnya seluruh nilai-nilai yang disebutkan dapat dimunculkan atau dibentuk asalkan ada sebuah narasi sebagai pijakan, dalam hal ini adalah keberadaan folklor. Sebagai contoh adalah keberadaan Sendang Sriningsih di Klaten. Pada awalnya tempat tersebut hanyalah mata air biasa saja namun, oleh para pengelolanya tempat tersebut diubah menjelma menjadi lokasi ziarah yang banyak menarik minat pengunjung. Hal tersebut tak lepas dari narasi-narasi ziarah yang diciptakan seperti; Setiap tanggal 30 April dan 30 September, mulai pukul 19.00 WIB diadakan prosesi oncor dari Gereja Santa Maria Marganingsih menuju bukit Golgota sendang Sriningsih sambil berdoa Jalan Salib sebagai tanda pembukaan bulan Maria dan bulan Rosario, yang kemudian dilanjutkan dengan Misa Kudus di sendang tersebut. Selain itu masih banyak ritual-ritual lainnya yang mengundang kehadiran banyak pengunjung.

\begin{tabular}{|c|c|c|c|c|c|c|}
\hline \multirow[b]{2}{*}{ Nilai } & \multicolumn{2}{|c|}{$\begin{array}{c}\text { Nilai } \\
\text { Mitologis }\end{array}$} & \multicolumn{2}{|c|}{ Nilai Religius } & \multicolumn{2}{|c|}{ Nilai Kesejarahan } \\
\hline & $\begin{array}{c}\text { Nilai } \\
\text { Lege } \\
\text { nda }\end{array}$ & $\begin{array}{l}\text { Nila } \\
\text { i } \\
\text { Mit } \\
\text { os }\end{array}$ & $\begin{array}{c}\text { Nilai } \\
\text { Prasej } \\
\text { arah }\end{array}$ & $\begin{array}{c}\text { Nilai } \\
\text { Sejar } \\
\text { ah }\end{array}$ & $\begin{array}{c}\text { Nilai } \\
\text { Arkeol } \\
\text { ogis }\end{array}$ & $\begin{array}{c}\text { Nilai } \\
\text { Dokume } \\
\text { ntasi }\end{array}$ \\
\hline
\end{tabular}

\begin{tabular}{l}
\hline Skor \\
max \\
\hline Skor \\
min \\
\hline Juml \\
ah
\end{tabular}

Keterangan: Sumber dari Irina-Maria Necheş (2013)

Melalui pengembangan alat ukur atau penilaian yang matang diharapkan didapatkan pula hasil atau lokasi yang memang benar-benar memiliki potensi pariwisata yang kuat. Selain itu kesinambungan antara pemberdayaan dan pelestarian budaya berjalan searah dengan pertumbuhan ekonomi masyarakat pemilik folklor. Sehingga kesadaran akan pentingnya melestarikan warisan leluhur dimiliki oleh masyarakat tumbuh secara alami.

\section{KESIMPULAN}

Banyaknya kekayaan sastra berupa folklor dapat dijadikan sebagai titik tumpu dalam pengembangan obyek wisata pada suatu daerah. Namun, dengan banyaknya potensi wisata yang dimiliki diperlukan sebuah strategi dalam rangka pengembangannya. Hal itu bukan hanya akibat terbatasnya anggaran, tapi 
juga agar lebih terfokus dan terarah secara jangka panjang. Salah satu cara penentuan atau pemilihan suatu lokasi dapat digunakan dengan metode penilaian/penskoran mengacu pada yang dirumuskan oleh Irina-Maria Necheş (2013) dengan penyesuaian sesuai kebutuhan.

\section{DAFTAR PUSTAKA}

Danandjaja, James. (2007). Folklor Indonesia. Jakarta: PT. Pustaka Grafiti Pers.

Djamaris, Edward. (1993). Nilai Budaya dalam beberapa Karya Sastra Nusantara: Sastra Daerah di Sumatra(Pusat Pembinaan dan Pengembangan Bahasa, Depdikbud.

Kusumaningrum, Dian. (2009). Persepsi Wisatawan Nusantara Terhadap Daya Tarik Wisata di Kota Palembang. Tesis PS. Magister Kajian Pariwisata. Universitas Gadjah Mada.

Pendit, Nyoman S. (1994). Ilmu Pariwisata Sebuah Pengantar. Perdana. Jakarta.

Irawan, Koko. (2010). Potensi Objek Wisata Air Terjun Serdang Sebagai Daya Tarik Wisata Di Kabupaten Labuhan Batu Utara. Kertas Karya. Program Pendidikan Non Gelar Pariwisata. Universitas Sumatera Utara.

Kemenpar. (2015). Rencana Strategis Pengembangan Destinasi dan Industri Pariwisata Kementerian Pariwisata Tahun 2015 -2019. Kemenpar RI.

Hamim Farhan dan R. Nazriyah. (2013). Prosiding Seminar Nasional. Peran Ekonomi dalam Pembangunan Nasional yang Berkelanjutan Gresik 29-30 Juni 2013: Pengembangan Pariwisata Berbasis Budaya Lokal-Budaya
Religi Sebagai Upaya Pendukung Peningkatan Industri Pariwisata Daerah Gresik.

Jaelani, Abdul Kadir. (2017). "Implikasi Berlakunya Peraturan Daerah Provinsi Nusa Tenggara Barat Nomor 2 Tahun 2016 Tentang Pariwisata Halal di Kota Mataram dan Kabupaten Lombok Timur". Tesis. Program Studi Magister Hukum Konsentrasi Hukum Kenegaraan Universitas Gadjah Mada. Yogyakarta.

Masri Ridwan, Ach.Fatchan, I Komang Astina. (2016). Potensi Objek Wisata Toraja Utara Berbasis Kearifan Lokal sebagai Sumber Materi Geografi Pariwisata. Jurnal Pendidikan: Teori, Penelitian, dan Pengembangan. Volume: 1 Nomor: 1 Bulan Januari Tahun 2016 Halaman: $1-10$

Necheş , I. (2011), "Geoheritage Conservation Through Geotourism. Case Study: The Bucegi Plateau", in Dombay, \$ ., Z. Magyari-Sáska (2011), The Role of Tourism in Territorial Development, IV International Conference Gheorgheni, Presa Universitar ă Clujean ă , ClujNapoca, pp. 141-148.

Nurdin. Strategi Pengembangan Pariwisata Berbasis Masyarakat Di Pulau Samalona, Makassar. JUMPA Volume 3 Nomor 1 Juli 2016. Hal 175-189

http://siarahgguamaria.blogspot.com/20 16/07/gua-maria-sriningsihklaten.html 24 Juli 2018

https://katadata.co.id/infografik/2015/02/ 17/pariwisata-andalan-penghasildevisa 25 Juli 2018

http://setkab.go.id/tahun-2017-kitagenjot-sektor-pariwisata/ 25 Juli 2018 
Tri Amanat

http://www.pikiran-

agramable-390062, 24 Juli 2018 rakyat.com/kolom/2017/01/og/inst 